\title{
The Effect of Experimental Vitamin D administering on the Calcium Metabolism in Adult Laying Hens
}

\author{
Nicolae DOJANĂ ${ }^{1 *}$, Claudia PREDA ${ }^{1}$, Rosalie BĂLĂCEANU ${ }^{2}$ \\ ${ }^{1}$ Department of Physiology, ${ }^{2}$ Department of Physiopathology, U.S.A.M.V. Bucharest, Splaiul \\ Independentei str., 105, 050097, Bucharest, Romania \\ *Corresponding author: dojana2001@yahoo.com
}

Bulletin UASVM Veterinary Medicine 71(2) / 2014,

Print ISSN 1843-5270; Electronic ISSN 1843-5378

DOI:10.15835/buasvmcn-vm: 10406

\begin{abstract}
.
The researches were performed on four groups of 34-week-age laying hens: a control group and three experimental groups treated with three levels of i.m. injected vitamin $\mathrm{D}_{2}$ doses (in IU / kg.b.w.: $0.2 \times 10^{5}, 1 \times 10^{5}$ and, respectively, $2 \times 10^{5}$ ), for 10 days. The results showed that Vitamin $\mathrm{D}_{2}$ treatment had a significant effect on shell dray matter weight: mean values were $5.89 \mathrm{~g} / \mathrm{egg}$ shell in control and 5.86, $6.35 \mathrm{and}$, respectively, $6.30 \mathrm{~g}$ DM in the three treated groups. Egg shell thickness was about 8\% higher in experimental groups vs. control, the percentage being higher in the groups that received higher vitamin $\mathrm{D}$ dose. The maximal amount of calcium removed by egg shell was $21 \%$ higher in vitamin $\mathrm{D}$ injected hens vs. control $(\mathrm{P}=0.0029)$. Mean tibia mineral content was $68 \mathrm{mg}$ ash /g bone higher in the three experimental groups vs. control. At the end of the experimental period, blood plasma calcium showed higher values vs. control $(\mathrm{P}=0.0098)$. Calcium removed by feces as unabsorbed or excreted in urine was significantly lower vs. control $(\mathrm{P}=0.0074)$. It was found that the largest amount of ingested calcium was lost through feces, as unabsorbed or excreted calcium. Calcidiol/calcitriol ratios ranged between 0.75 and 1.52 in the experimental groups, vs. 0.40 in control. In conclusion, ascending doses of vitamin D in laying hens improve the calcium absorption during the peak of the egg cycle, increase the plasma calcium levels, the content of the egg shell calcium and bone mineral content but the main ingested calcium remains lost by feces. The effects are not proportional with the vitamin $\mathrm{D}$ doses.
\end{abstract}

Keywords: adult laying hens, calcium metabolism, vitamin D,

\section{INTRODUCTION}

Calcium metabolism regulation in laying hens involves the concerted action of a complex of hormonal factors, which have to satisfy the exaggerated egg calcium export requirements. Involvements of vitamin D are at the gut level (absorption), bone level (deposition / mobilization) and oviduct level (egg shell deposition). The exact requirements and the mechanism by which vitamin $D$ is involved at this level are not yet sufficiently known. This paper therefore has the research topic the involvement of different vitamin D levels in calcium metabolism (absorption, deposition, excretion) in laying hens in full lay cycle.

\section{MATERIAL AND METHODS}

The researches were performed on four groups of adult (34-week-age) White Leghorn laying hens: a control group and three experimental groups, 10 capita each one. The three experimental groups were treated with three levels of vitamin D supplements. Supplementation with vitamin D was performed by intramuscular administration of "Vitamina $D_{2}$ " (Terapia s.a.) in the following doses (in IU / kg.b.w.): $0.2 \times 10^{5}$ (group A), $1 \times 10^{5}$ (group B) and, respectively, $2 \times 10^{5}$ (group C), once a day for 10 days. Forage and drinking water were provided ad libitum and it was applied a photoperiod program of $16: 30 \mathrm{~h}$ artificial light/7:30 $\mathrm{h}$ dark. During the experimental period, they were monitored the amount of forage intake and egg production. Egg shell thickness, egg shell calcium concentration, the amount of calcium eliminated in dejections (feces and urine), bone mineral content and blood plasma calcium were determined at the end of the experimental 
treatment. Blood levels of the calcidiol and calcitriol were determined also at the end of the experimental treatment in all the groups and calcidiol/calcitriol ratio was calculated. Calcium contents from forages, dejections, bone (tibia) and egg shell were determined using a TRACE 1300 ANALYZER. Previously, samples were calcinated at $500^{\circ} \mathrm{C}$. The thickness of the eggshell was measured using a micrometer. Blood calcium concentration was determined by Elliot method, according to Manta et al. (1976). Blood calcidiol and calcitriol contents were determined by ECLIA method using a COBAS e 411 ANALYZER. Data were statistically processed by ANOVA using a statistical analysis software program (SAS/STAT, Version 8.0; SAS Institute Inc., Cary, NC, USA). The results are presented as mean \pm s.d. and significance was considered for $\mathrm{P}<0.05$.

\section{RESULTS AND DISCUSSION}

As it resulted from Table 1, higher experimental doses of vitamin $D$ induced a significant increase of the egg shell weight: $7.8 \%$ in group B and 6.9\% in group C. A similar situation was found for egg shell thickness, except the fact that in this case, all the experimental doses induced a significant increase of the egg shell thickness: $9.0 \%$ in group $\mathrm{A}$ and $7.5 \%$ in groups B and C. On the other hand, egg shell calcium concentrations were found significant higher in experimental treated group vs. control: $2.7 \%, 8.0 \%$ and $8.7 \%$, respectively. As a consequence, daily egg shell calcium output was found higher also, for all the three experimental groups: $12.3 \%$ for group A, $17.4 \%$ for group B and $21.7 \%$ for group C.

Plaimast and Kijparkorn (2010) reported significant increases in the thickness of shell eggs from hens aged 98 weeks following administration for 8 weeks a calcium supplement, with or without association of vitamin D supplements, finding significant effects of increasing the thickness of the shell only when calcium in the diet was associated with vitamin D supplements. Our results revealed an effect of increasing of the egg shell thickness and egg shell calcium concentration. But the increase is not dose-proportional.

Blood plasma calcium was $11.1 \%, 17.3 \%$ and $21.7 \%$, respectively, higher in the three treated groups vs. control. Mean tibia mineral content was $68 \mathrm{mg} / \mathrm{g}$ bone higher in the three experimental groups vs. control. According to Golden and Arbona (2012), femur bone mineral content in laying hens have been shown to decline during the first few weeks of egg production, which can be attributed to factors such insufficient dietary intake of calcium, phosphorus and vitamin D.

Analysis of the data presented in Table 1 shows the increase in serum calcium gives a higher amount of tibia ash in the experimental treated groups compared to control. The differences were statistically significant even from the group A, treated with the lowest dose of vitamin D. This

Tab. 1. Food intake, calcium intake, egg production, egg shell properties in the 34-week-age White Leghorn hen groups treated with vitamin $\mathrm{D}_{2}$ for 10 days (mean for item 1-3, mean \pm s.d. for item 4-10)

\begin{tabular}{lccccc}
\hline & Control & $\begin{array}{c}\text { Group A } \\
\left(0,2 \times 10^{5} \mathrm{IU}\right. \\
\text { vitamin D) }\end{array}$ & $\begin{array}{c}\text { Group B } \\
\left(1 \times 10^{5} \mathrm{IU}\right. \\
\text { vitamin D) }\end{array}$ & $\begin{array}{c}\text { Group C }\left(2 \times 10^{5}\right. \\
\text { IU vitamin D) }\end{array}$ & P value \\
\hline Food intake (g/cap./day) & 115.15 & 114.05 & 115.0 & 117.50 & \\
\hline Calcium intake (g/cap./ day) & 4.88 & 4.84 & 4.86 & 4.97 & \\
\hline Egg production (pieces/cap./day) & 0.82 & 0.79 & 0.83 & 0.86 & \\
\hline Egg shell weight (g DM) & $5.89 \pm 0.55$ & $5,86 \pm 1,06$ & $6,35 \pm 2,09$ & $6,30 \pm 0,43$ & 0.0497 \\
\hline Egg shell thickness ( $\mu \mathrm{m})$ & $265 \pm 26$ & $289 \pm 23$ & $285 \pm 24$ & $285 \pm 16$ & 0.0039 \\
\hline Egg shell calcium concentration & $287 \pm 22$ & $294 \pm 29$ & $310 \pm 8$ & $312 \pm 12$ & 0.0165 \\
(mg/gDM) & $1.380 \pm 41$ & $1,550 \pm 49$ & $1.620 \pm 87$ & $1.680 \pm 84$ & 0.0029 \\
\hline Daily egg shell calcium output (mg) & $11.04 \pm 1.11$ & $12.00 \pm 1.75$ & $13.87 \pm 2.85$ & $13.95 \pm 1,66$ & 0.0098 \\
\hline Blood plasma calcium (mg/dL) & $390 \pm 11$ & $439 \pm 22$ & $472 \pm 20$ & $460 \pm 13$ & 0.0122 \\
\hline Tibia mineral content (in mg ash /g bone) & & & & &
\end{tabular}

Legend: $\mathrm{DM}=$ dry matter, weight of the desiccated egg shell at $105^{\circ} \mathrm{C}$ $\mathrm{IU}=$ international units. 
enables us to say that the given hormone showed a stimulating effect on the absorption of calcium from food, whose surplus is responsible for raising serum calcium and increased calcium depots in the bones. Similar effects were reported by Preda (2014) in 22-week-old ROSO hens.

Turgut et al. (2006) found increased serum levels of vitamin D in the case of food supplementation with this vitamin in adult laying hens, but the increase of serum calcium was not proportional to the increase of vitamin D dose.

The values of the calcium excreted by feces and urine are presented in Table 2. The values from Table 2 should be understood taking into account that not all the calcium found in dejections is a non-absorbed calcium: little percent of this calcium get here as calcium excreted by the kidney. But the data can characterize the intensity of gastrointestinal absorption of calcium given the low percentage of calcium excreted in the urine: about 3\% of ingested calcium (Dojana, 2013). The amount of exonerated calcium was lower in experimentally treated group vs. control (in $\mathrm{mg} /$ day/cap.): by 228 in group A, 266 in group B and 252 in group C.

Blood plasma concentrations of calcidiol and calcitriol at the end of the 10 days of Vitamin $\mathrm{D}_{2}$ experimental treatment period are presented in Table 3. According to the data presented in Table 3, group B received a vitamin D supplement five times higher than in group $\mathrm{A}$ while $\mathrm{C}$ group were given an additional three times higher than in the groups B. But blood plasma amount of calcidiol is about three times higher in the groups B vs. group A and about 0.5 time higher in groups $C$ vs. B. Regarding the calcitriol concentrations, differences between groups are even lower than those of calcidiol. Calcidiol/calcitriol ratios for the three treated groups increased from one to another, according to the size of the dose. According to these data,

Tab. 2. The mean calcium concentration and the amount of calcium removed in the dejections within 24 hours in the groups of hens subjected to the experimental treatment with different doses of vitamin $\mathrm{D}_{3}$ (colecalciferol) vs. control

\begin{tabular}{|c|c|c|c|c|c|}
\hline & Control & $\begin{array}{c}\text { Group A } \\
\left(0,2 \times 10^{5} \mathrm{IU}\right. \\
\text { vitamin D) }\end{array}$ & $\begin{array}{c}\text { Group B } \\
\left(1 \times 10^{5} \mathrm{IU}\right. \\
\text { vitamin D) }\end{array}$ & $\begin{array}{c}\text { Group C } \\
\left(2 \times 10^{5} \mathrm{IU}\right. \\
\text { vitamin D) }\end{array}$ & Notifications \\
\hline $\begin{array}{l}\text { Dejections exonerated in } 24 \text { hours } \\
\text { (g DM/day/cap.) }\end{array}$ & 33 & 35 & 33 & 36 & $\begin{array}{l}\text { Obtained by } \\
\text { harvesting an } \\
\text { calcination } \\
\text { at } 105^{\circ} \mathrm{C}\end{array}$ \\
\hline $\begin{array}{l}\text { Calcium concentration in } \\
\text { dejections }(\mathrm{mg} / \mathrm{g} \mathrm{DM})\end{array}$ & 102.66 & 90.28 & 94.6 & 87.11 & $\begin{array}{c}\text { Laboratory } \\
\text { determination }\end{array}$ \\
\hline $\begin{array}{l}\text { Amount of calcium exonerated } \\
\text { by dejections (mg/day/cap.) }\end{array}$ & 3.388 & 3.160 & 3.122 & 3.136 & Calculation \\
\hline
\end{tabular}

Legend: as in Table 1

Tab. 3. Blood plasma concentration of calcidiol and calcitriol in 34-week-age White Leghorn hens following 10 days of treatment with various doses of vitamin D vs. untreated control

\begin{tabular}{lccccc}
\hline & Control & $\begin{array}{c}\text { Group A } \\
\left(0,2 \times 10^{5} \text { UI }\right. \\
\text { vit.D/ day })\end{array}$ & $\begin{array}{c}\text { Group B } \\
\left(1 \times 10^{5} \text { UI }\right. \\
\text { vit D/day })\end{array}$ & $\begin{array}{c}\text { Group C } \\
\left(1,5 \times 10^{5} \text { UI }\right. \\
\text { vit. D/day })\end{array}$ & P value \\
\hline Calcidiol $(\mathrm{ng} / \mathrm{mL})$ & $20.1 \pm 3,7$ & $66.6 \pm 8.7$ & $211.1 \pm 22.5$ & $321.0 \pm 20.4$ & 0.0011 \\
\hline Calcitriol $(\mathrm{pg} / \mathrm{mL})$ & $50.0 \pm 2,8$ & $88.8 \pm 6.8$ & $197.5 \pm 17.5$ & $210.0 \pm 22.5$ & 0.0288 \\
\hline Calcidiol $/$ Calcitriol & 0.40 & 0.75 & 1.06 & 1.52 & \\
\hline
\end{tabular}


serum levels of calcidiol increase in response to vitamin D supplementation, but the increase is not linear, for reasons that are poorly known. In March 2007, a group of researchers published a controversial and provocative editorial by stating that normal levels of calcidiol are $\geq 75 \mathrm{nmol} / \mathrm{L}$ ( $\geq 30 \mathrm{ng} / \mathrm{mL}$ ) in human. They have shown that it takes approximately 1,700 IU / day of vitamin D in order to achieve an increase in serum calcidiol from 50 to $80 \mathrm{nmol}$ (from 20 to $32 \mathrm{ng} / \mathrm{mL}$ ) (Schmidt-Gayk et al., 1997).

\section{CONCLUSION}

Different doses of vitamin $D$ in laying hens improve the calcium absorption during the pick of the egg laying cycle, increase the plasma calcium levels and the content of the calcium egg shell and bone mineral content but the main ingested calcium is lost by feces. The effects are not proportionally with the vitamin $\mathrm{D}$ doses.

\section{REFERENCES}

1. Dojana N (2013). Treatise of animal physiology and ethology. Printech, Bucharest, RO.
2. Golden JB, Arbona DV (2012). Intensive versus extensive management systems in commercial egg production. Animal Science Reviews, p. 157.

3. Manta I, Cucuianu M, Benga G, Hodârnău A (1976). Biochemical methods in clinic laboratory. Dacia, ClujNapoca, RO.

4. Pelicia K, Garcia EA, Faitarone ABG, Silva AP (2009). Calcium and Available Phosphorus Levels for Laying Hens in Second Production Cycle. Brazilian Journal of Poultry Science. 11(1): 39- 49.

5. Plaimast H, Kijparkorn S (2010). Effects of Supplementary Vitamin $\mathrm{D}_{3}$ on Eggshell Quality and Vitamin $\mathrm{D}_{3}$ Content in Egg of Aged Hens Fed Different Levels of Calcium. Proc. $9^{\text {th }}$ Vet. Sci. Ann. Con.

6. Preda C (2014). Particularities regarding the calcium metabolism regulation during the laying cycle in hen.U.S.A.M.V. Bucharest, PhD Diss. Abstr., p. 5-8.

7. Schmidt-Gayk H, Bouillon R, Roth HJ (1977) Measurement of vitamin D and its metabolites (calcidiol and calcitriol) and their clinical significance. Scand. J. Clin. Lab. Invest. Suppl.; 227:35-45.

8. Turgut L, Hayirli A, Çelebi S., Yörük MA, Gül M, Karaoğlu M, Macit M (2006) The Effects of Vitamin D Supplementation to Peak-producing Hens Fed Diets Differing in Fat Source and Level on Laying Performance, Metabolic Profile, and Egg Quality. Asian-Aust. J. Anim. Sci. 19(8), 1179 - 1189. 